Environment Conservation Journal 14(3) 85-90, 2013

ISSN 0972-3099 (Print) 2278-5124 (Online)

Abstracted and Indexed

\title{
Ambient air quality of Katra town, J\&K during fireworks on Diwali festival
}

\author{
Anil K. Raina $\bowtie$ and Anita Sharma
}

Received: 25.06.2013

Accepted: 19.08.2013

\begin{abstract}
Diwali-the festival of lights, is celebrated in India, every year during October or November with great fireworks display which contributes to pollution of air. In order to assess the impacts of fireworks on ambient air quality during Diwali festival in Katra town, Jammu , (J\&K); monitoring of RSPM, NRSPM, $\mathrm{SO}_{2}$ and $\mathrm{NO}_{2}$ during day and night times for PreDiwali (day before Diwali); Diwali and Post-Diwali (day after Diwali) for two successive years i.e. 2011 and 2012 has been carried out in a residential area. The air quality levels observed on Diwali has been compared with the air quality levels observed before and after Diwali which has revealed considerable increase in RSPM, NRSPM, $\mathrm{SO}_{2}$ and $\mathrm{NO}_{2}$ concentration due to Diwali fireworks. On Diwali day, the concentration of RSPM, NRSPM, TSPM, $\mathrm{SO}_{2}$ and NO $\mathrm{NaS}_{2}$ found to be $118.27 \mu \mathrm{g} / \mathrm{m}^{3}, \quad 153.2 \mu \mathrm{g} / \mathrm{m}^{3}, \quad 271.47 \mu \mathrm{g} / \mathrm{m}^{3}, 6.61 \mu \mathrm{g} / \mathrm{m}^{3}$ and $10.51 \mu \mathrm{g} / \mathrm{m}^{3}$ respectively in 2011 and $141.2 \mu \mathrm{g} / \mathrm{m}^{3}$, $199.14 \mu \mathrm{g} / \mathrm{m}^{3}, 340.34 \mu \mathrm{g} / \mathrm{m}^{3}, 7.06 \mu \mathrm{g} / \mathrm{m}^{3}$ and $10.53 \mu \mathrm{g} / \mathrm{m}^{3}$ respectively in 2012 .These concentrations were found to be 1.75 , 1.57, 1.65, 1.73 and 1.52 times higher in 2011 and 1.86, 2, 2, 1.47 and 1.39 times higher in 2012, when compared with the respective concentrations of normal day. The higher level of these pollutants due to fireworks during Diwali festival poses serious health hazards to the inhabitants of the area.
\end{abstract}

Keywords: Ambient air quality, Katra town, Diwali, $\mathrm{SO}_{2}, \mathrm{NO}_{2}, \mathrm{RSPM}, \mathrm{NRSPM}$

\section{Introduction}

In India, festival of lights (Diwali) is celebrated with great enthusiasm every year during October/ November and is associated with the bursting of huge amount of crackers and burning of sparkles. In fact, crackers have become an integral part of the festival to the extent that now a day this festival of light has almost solely been associated with the sound of crackers and has turned into a festival of pollution, noise and serious health hazards (http://mpcb.mah.nic.in.). It starts few days before the festival and becomes very intense in the evening hours on Diwali day. The use of fire crackers with brighter sparkles and louder noise seems most essential and appropriate in a Diwali festival but the temporary joy and happiness leads to hazardous air pollution as these firecrackers releases various gaseous and particulate air pollutants and toxic metals to significant quantities and degrades the air quality as a whole (Attri et al., 2001; Wang et al., 2007; Zhang et al., 2010; Chatterjee et al., 2012; Licudine et al., 2012 and Wang et al., 2012).Various studies conducted at different places has also indicated short term variation of air quality and increased particulates

\section{Author's Address}

P.G. Department of Environmental Sciences,

University of Jammu

Email: anilkraina@yahoo.com concentration (Ravindra et al.,2003a; Barman et al., 2008; Singh et al., 2010; Suresh et al., 2010; Mandal et al., 2012). These particles can penetrate deep into the respiratory system and studies indicate that smaller the particle, more severe the health effects (Pope and Dockery, 2006; Thakur et al., 2010). Diwali-related pollution has a bearing on the atmospheric temperature also. Extensive bursting of crackers may lead to an increase in temperature by as much as $2^{0} \mathrm{C}$, especially in densely populated areas, during that period (www.toxicslink.org).Katra, a famous pilgrim centre of India, is located in the District Reasi, J\&K and is $48 \mathrm{~km}$ away from Jammu city. The town lies at $32^{0} 59 \mathrm{~N}$ latitude and $74^{0} 55 \mathrm{E}$ longitude; at an average altitude of 2840 feet above the mean sea level on way to Shri Mata Vaishno Devi Shrine on the western side of sub-Himalayan ranges i.e. Shivalik hills. Hundreds of thousands of people visit this town along with their vehicles which contribute for the pollution of the air. Bursting of crackers and burning of fireworks during Diwali festival which generate huge amount of particulate matter as well as gaseous pollutants, ultimately aggravate the pollution level of the town. In order to assess the short term effects of fireworks on local environment of Katra town, sampling of 
particulates, $\mathrm{SO}_{2}$ and $\mathrm{NO}_{2}$ was conducted during Pre Diwali, Diwali and Post Diwali days in the residential area namely Paharganj.

\section{Material and methods}

Air sampling was carried out by using High Volume Air Sampler (Envirotech Model 460 BL ). The sampling instrument was fixed at a breathing height of $1.5-2 \mathrm{~m}$ above the ground level. The sampling was carried out during day and night time for 8 hours. The respirable fraction (RSPM or $\mathrm{PM}_{10}$ ) was collected on pre-weighed Whatman glass microfiber filter paper ( G/F, $20.3 \times 25.4 \mathrm{~cm}$ ). Particles in the size range of $(10-100 \mu \mathrm{m})$ were collected in a separate sampling bottle. The filter paper and sampling bottle were re-weighed after sampling in order to determine the mass of particles collected (Gravimetric Method, BIS, Part-IV, 1973).For the collection of gaseous pollutants i.e. $\mathrm{SO}_{2}$ and $\mathrm{NO}_{2}$, Modified West and Gaeke method (BIS- Part- II, 1969) and Jacob and Hochheiser
(BIS-Part VI, 1975) modified method was followed respectively. A known quantity of air was passed through the impingers containing known volume of absorbing solution; $\mathrm{SO}_{2}$ is absorbed in absorbing solution, sodium tetrachloromercurate. A dichlorosulphitomercurate complex is formed which is made to react with pararosaaniline and methylsulphonic acid wheras $\mathrm{NO}_{2}$ was absorbed in absorbing solution, sodium hydroxide- sodium arsenite which formed a stable solution of sodium nitrite. The samples were analysed spectrophotometrically by measuring absorbance at a wavelength of 560 for $\mathrm{SO}_{2}$ and 540 for $\mathrm{NO}_{2}$.

\section{Results and discussion}

The eight hourly average day and night ambient concentrations of RSPM, NRSPM, $\mathrm{SO}_{2}$ and $\mathrm{NO}_{2}$ on Pre-Diwali, Diwali and Post-Diwali day at Paharganj (residential) area of Katra town is presented in table 1. TSPM calculated from above findings has also been calculated.

Table 1: Concentration of RSPM, NRSPM, TSPM, $\mathrm{SO}_{2}$ and $\mathrm{NO}_{2}$ of normal, Pre-Diwali, Diwali and PostDiwali days

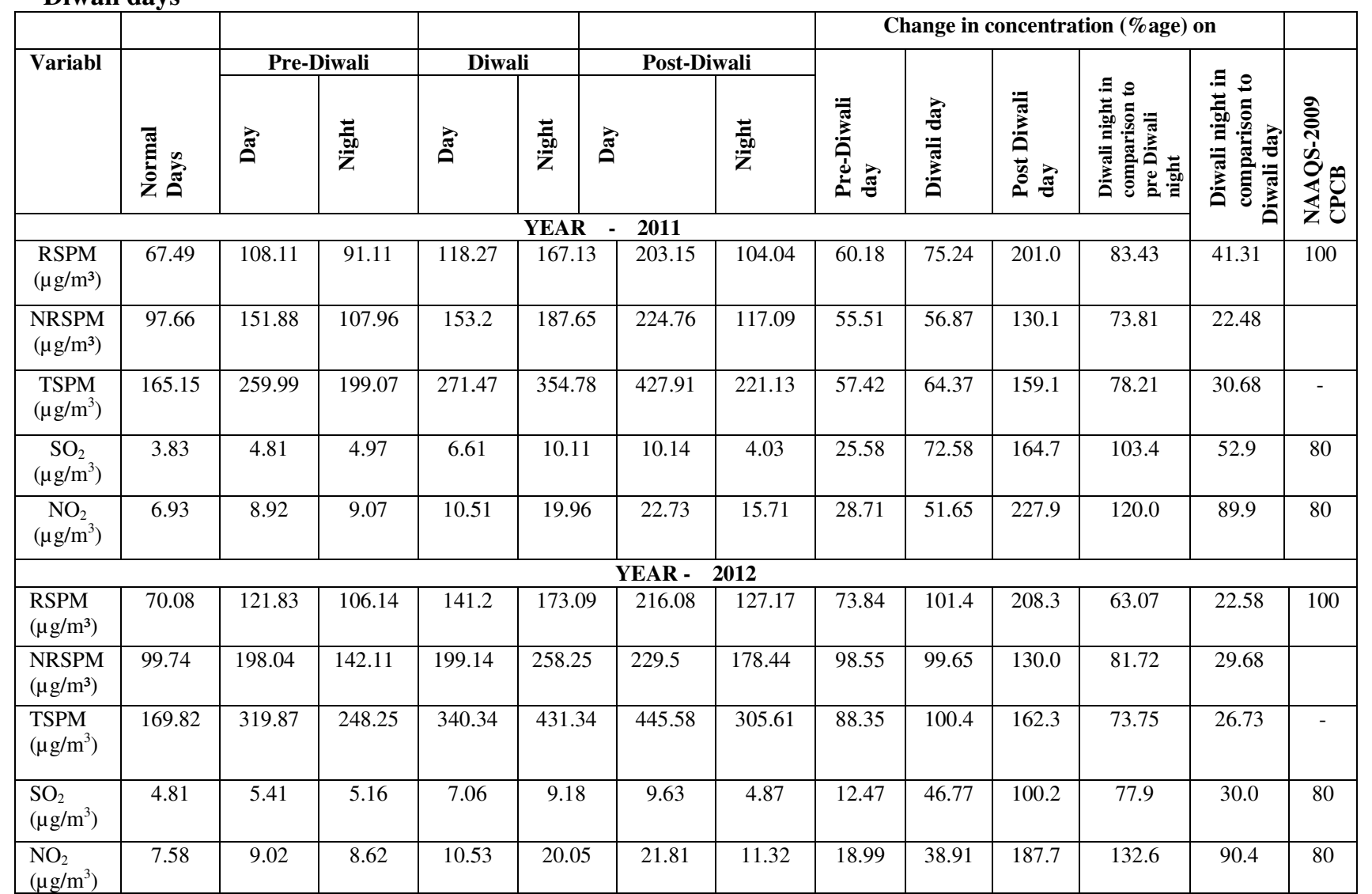

Note: The standard for SPM parameter was eliminated from NAAQS vide gazzete notification no.G.S.R.826 (E) dated 16th Nov., 2009 
Besides this, the average ambient concentrations of these pollutants on normal days (10-12 days before Diwali) is also presented in table 1 for comparison with Pre-Diwali, Diwali and Post- Diwali days. On Diwali night, average concentration of RSPM, NRSPM, TSPM, $\mathrm{SO}_{2}$ and $\mathrm{NO}_{2}$ was found to be $1.42,1.31,1.35,1.53$ and 1.9 times higher than their respective daytime levels in 2011 and 1.23, $1.3,1.27,1.3$ and 1.9 times higher than their respective daytime levels in 2012 respectively. Furthermore, the average daytime concentration of RSPM, NRSPM, TSPM, $\mathrm{SO}_{2}$ and $\mathrm{NO}_{2}$ on Diwali day was found to be higher than the previous daytime (Pre-Diwali) concentration by 1.1, 1.02, $1.01,1.4$ and 1.18 times respectively in the year
2011 and $1.16,1.01,1.07,1.31$ and 1.17 times, respectively in the year 2012.The increase in concentration of pollutants on the Diwali day in spite of lesser use of fireworks during day hours, lesser inflow of tourists and vehicles, indicated a longer residence time of these pollutants in the ambient air accumulated on Pre-Diwali night due to fireworks. Higher concentrations of Post-Diwali daytime (with no firework activities) also indicated the effect of Diwali night firework activities. Increased number of pilgrims on the Post-Diwali day, resulting in increased traffic movement, during both the monitoring years (table 2) has also contributed towards the higher concentrations of pollutants on post Diwali day.

Table II: Number of tourists visited Katra town during the days of monitoring

\begin{tabular}{|c|c|c|}
\hline YEAR & DAY & $\begin{array}{c}\text { Number of tourists entering Katra } \\
\text { town }\end{array}$ \\
\hline \multirow{3}{*}{ 2011( October) } & Pre Diwali $\left(25^{\text {th }}\right.$ Oct. $)$ & 13153 \\
\hline & Diwali (26 $6^{\text {th }}$ Oct.) & 19094 \\
\hline & Post Diwali (27 $7^{\text {th }}$ Oct.) & 30156 \\
\hline \multirow{3}{*}{ 2012( November) } & Pre Diwali (12 ${ }^{\text {th }}$ Nov.) & 13644 \\
\hline & Diwali (13 ${ }^{\text {th }}$ Nov.) & 17618 \\
\hline & Post Diwali (14 ${ }^{\text {th }}$ Nov.) & 24268 \\
\hline
\end{tabular}

\section{Source: Yatra Registration Counter, Katra}

Moreover during day-time, several anthropogenic activities, viz. burning of coal, wood, LPG, tourists and vehicular activities, were higher resulting higher emissions of pollutants than night time.Diurnal pattern of RSPM, NRSPM,TSPM, $\mathrm{SO}_{2}$ and $\mathrm{NO}_{2}$ concentration on pre Diwali, Diwali and post Diwali periods showed a increase in their concentrations on Diwali night as compared to Diwali day time which seems to be associated with increased use of fireworks during the night. Thus, it is clear that there was a strong effect of night-time firework activities on the next day-time concentrations. As the firework activities during Diwali night were higher than that during PreDiwali night, the daytime concentrations of RSPM, NRSPM, TSPM, $\mathrm{SO}_{2}$ and $\mathrm{NO}_{2}$ on post Diwali day was also higher than that on Diwali day.The concentrations of studied pollutants have also been observed to be higher when compared to day-time concentrations of normal day, thereby showing the strong effect of firework activities on ambient air quality. The change in concentration (percentage) of these pollutants on pre Diwali, Diwali and post Diwali days in comparison to normal days, Diwali night as compared to pre Diwali night and Diwali night in comparison to Diwali day is also shown in the table I.The concentration of gaseous pollutants i.e. $\mathrm{SO}_{2}$ and $\mathrm{NO}_{2}$ was found to be within the permissible limits of NAAQS of CPCB, 2009 presented in table I, however the concentration of both these pollutants increased during Diwali as compared to its usual levels ascertained through regular monitoring whereas the concentration of RSPM was found to be high as compared to permissible limits of NAAQS (CPCB, 2009). Various studies have revealed that meteorological factors like wind speed, relative humidity, precipitation and temperature play a very important role in the dispersion of air pollutants (Ravichandran et al., 2001; Ravindra et al., 2003, Karar et al., 2005; Gallero et al., 2006, Bhaskar and Mehta, 2010). Wind speed and precipitation is considered to be inversely proportional to the concentration of pollutants. Average concentration 
of pollutants is higher with low temperature. In Diwali season; calm conditions generally prevail that also aggravate the air quality status. The different meteorological parameters like temperature, relative humidity, wind speed and wind direction have been shown in table III for Pre Diwali, Diwali and Post Diwali days which revealed that there is decrease in average temperature, increase in humidity profile and slightly lower wind speed on the day of Diwali in 2012 as compared to 2011. It has influenced the air quality resulting in higher concentration of pollutants in 2012 as compared to 2011. Similar air quality studies have been carried out during Diwali in Hisar (Ravindra et al., 2003a), Lucknow

(Barman et al.,2008), Howrah ( Thakur et al., 2010) and Delhi ( Mandal et al., 2012) and Nagpur (Rao et al., 2012) which have also reported similar pattern of deterioration of short-term air quality and several times higher concentration of $\mathrm{SPM}, \mathrm{SO}_{2}$ and $\mathrm{NO}_{2}$ during the study period. Similarly, several times increase of $\mathrm{PM}_{10}, \mathrm{SO}_{2}$ and $\mathrm{NO}_{\mathrm{x}}$ than the normal day values were reported by Muchate and Chougule, 2011; Do et al., 2012; CPCB, New Delhi during the Diwali in Delhi, India (http://www.cseindia.org) and Rajasthan State Pollution Control Board, (www.indiaenvironmentportal.org.in).

Table 3: Meteorological parameters recorded during the monitoring period

\begin{tabular}{|c|c|c|c|c|c|c|}
\hline Variables & \multicolumn{2}{|c|}{ Temperature } & \multicolumn{2}{|c|}{ Relative Humidity } & Wind Speed & Wind Direction \\
\hline \multicolumn{7}{|c|}{ Year 2011} \\
\hline \multirow[b]{2}{*}{ Pre Diwali } & Max. & Min. & Max. & Min. & & \\
\hline & 26.8 & 12.8 & 74 & 64 & 01 & Calm \\
\hline Diwali & 25.3 & 13.4 & 65 & 64 & 02 & South-easterly \\
\hline Post Diwali & 25.7 & 12.7 & 72 & 62 & 02 & South-easterly \\
\hline \multicolumn{7}{|l|}{ Year 2012} \\
\hline Pre Diwali & 22.6 & 11.6 & 77 & 74 & 01 & Calm \\
\hline Diwali & 24.0 & 10.6 & 79 & 67 & 01 & Calm \\
\hline Post Diwali & 24.8 & 10.6 & 76 & 72 & 02 & South-easterly \\
\hline
\end{tabular}

Source : Regional Meteorological Centre, Srinagar.

The elevated concentration of SPM, $\mathrm{SO}_{2}$ and $\mathrm{NO}_{2}$ and trace metals with particulate matters have direct relation with adverse human health as well on the environment (Agarwal et al., 2006, Nidhi and Jayaraman, 2007 and Sagar et al., 2007; and Khaparde et al., 2012).Thus increase in particulate mass concentration, $\mathrm{SO}_{2}$ and $\mathrm{NO}_{2}$ during Diwali period may be attributed to both the cracker emissions and stable atmospheric conditions in winter.

\section{Conclusion}

This study shows that the bursting of crackers and burning of sparkles on the occasion of Diwali is a strong source of particulate matter, $\mathrm{SO}_{2}$ and $\mathrm{NO}_{2}$ in ambient air which are emitted in high quantity as compared to non-Diwali days. The higher level of air pollutants especially particulate matter is of great concern with regard to the health effects.
Hence, for the benefit of society, it is necessary to formulate proper strategy to control the emission and subsequent dispersion of pollutants. Following measures may be considered:

1. Prohibition of firecracker burning on roads/lanes and earmarking of large open spaces, away from residential area, for firework display.

2. Mass awareness campaign should be conducted by Government through press and electronic media regarding health effects of cracker burning so that people may take safety measures during Diwali.

3. Crackers, exploding at a higher elevation may be encouraged for better dispersion. 


\section{References}

Agarwal,R., Jayaraman,G., Anand,S. and Marimuthu,P., 2006. Assessing respiratory morbidity through pollution status and meteorological conditions for Delhi. Environmental Monitoring and Assessment, 114: 489-504.

Attri, A.K., Kumar,U. and Jain, V.K., 2001. Microclimate: Formation of ozone by fireworks. Nature, 411 (6841), 1015.

Barman, S.C., Singh, R., Negi, M.P.S. and Bhargava, S.K., 2008. Ambient air quality of Lucknow city (India) during use of fireworks on Diwali festival. Environmental Monitoring and Assessment, 137 : 495-504.

Bhaskar, B.V. and Mehta,V.M., 2010. Atmospheric particulate pollutants and their relationship with meteorology in Ahmedabad. Aerosol and Air Quality Research, 10 : 301315.

Bureau of Indian Standard (BIS), 1969, 5182 Part II, sulphur dioxide Indian Standard Institute, New Delhi.

Bureau of Indian Standard (BIS), 1973. 5182 Part- IV Method of measurement of air pollutants- suspended particulate matter, 5182 Part VI, Indian Standard Institute, New Delhi.

Bureau of Indian Standards (BIS), 1975, 5182 Part- VI, nitrogen dioxide, Indian Standard Institute, New Delhi.

Centre for Science and Environment, 2012. Pollution caused from Diwali crackers. http:///www.cseindia.org/.

Chatterjee, A., Sarkar,C., Adak,A., Mukherjee, U., Ghosh, S.K. and Raha, S., 2012. Ambient air quality during Diwali festival over Kolkata- A mega city in India. Aerosol and Air Quality Research, X ; 1-12, xxxx.

CPCB, 2009. National Ambient Air Quality Standards. Central Pollution Control Board, Parivesh Bhavan, India. http: //cpcb.nic.in/.

Do,T.M., Wang,C.F., Hsieh,Y.K. and Hsieh,H.F., 2012. Metals present in ambient air before and after a firework festival in Yanshui, Tainan, Taiwan. Aerosol and Air Quality Research, 12 : 981-993.

Gallero,F.J.G., Vallejo, M.G., Umbria, A. and Baena, G., 2006. Multivariate statistical analysis of meteorological and air pollution data in the Campo De Gibralter Region, Spain. Environmental Monitoring and Assessment, 119 : 405423.

http:///www.cseindia.org/., 2012. Pollution caused from Diwali crackers. Report of Centre for Science and Environment, New Delhi. http://mpcb.mah.nic.in., 2007. Monitoring of noise and air pollution during Diwali. Report of Maharashtra Pollution Control Board.

Karar, K., Gupta, A.K., Kumar, A., Biswas, A.K. and Devotta, S., 2005. Statistical interpretation of weekday/weekend differences of ambient gaseous pollutants, vehicular traffic and meteorological parameters in urban region of Kolkata. Journal of Environmental Science and Engineering, 47(3) : 164-175.

Khaparde,V.V., Pipalatkar,P.P., Pustode,T., Rao, C.V.C. and Gajghate, D.G., 2012. Influence of burning of fireworks on particle size distribution of $\mathrm{PM}_{10}$ and associated Barium at Nagpur. Environmental Monitoring and Assessment,184 : 903-911.

Licudine, J.A., Yee, H., Chang, W.L. and Whelen, A.C., 2012. Hazardous metals in ambient air due to new year fireworks during 2004-2011 celebrations in Pearl city, Hawaii. Environmental Health and Public Health Report, 127 : 440-450.

Mandal,P., Prakash,M. and Bassin,J.K., 2012. Impact of Diwali celebrations on urban air and noise quality in Delhi city, India. Environmental Monitoring and Assessment, 184 : 209-215.

Muchate, N.S. and Chougule, A.M., 2011. Study on ambient concentration of air quality parameters $\left(\mathrm{PM}_{10}, \mathrm{SPM}, \mathrm{SO}_{2}\right.$ and $\mathrm{NO}_{\mathrm{x}}$ ) in different months. European Journal of Experimental Biology,1(1) : 90-96.

Nidhi and Jayaraman, 2007. Air quality and respiratory health in Delhi. Environmental Monitoring and Assessment, $135: 313-325$.

PopeIII, C.A. and Dockery,D.W., 2006. Health effects of fine particulate air pollution : Lines that connect. Air and Waste Management Association, 56 : 709-742.

Rao,P.S., Gajghate,D.G., Gavane, A.G., Suryawanshi, P., Chauhan ,C., Mishra, S., Gupta, N., Rao, C.V.C. and Wate, S.R., 2012. Air quality status during Diwali festival of India: A case study. Bulletin of Environmental Contamination and Toxicology, 89 : 376-379.

Ravichandaran,C., Chandrasekaran,G.E., Shalini,V. and Venkatasubramanian,R., 2001. Impact of Deepavali fireworks on air quality and noise levels in Tiruchirapalli. Indian Journal of Environmental Protection,21(8) : 677682 .

Ravindra, K., Mor, S., Ameena, Kamyotra,J.S. and Kaushik,C.P., 2003. Variation in spatial pattern of criteria air pollutants before and during initial rain of monsoon. Environmental Monitoring and Assessment, 87 : 145153. 


\section{Raina and Sharma}

Ravindra,K., Mor,S. and Kaushik,C.P., 2003. Short-term variation in air quality associated with fireworks events: A case study. Journal of Environmental Monitoring, 5 : 260-264.

Report, 2007. Monitoring of noise and air pollution during Diwali. http: // mpcb.mah.nic.in.

Report, 2012. Status report of noise level/ambient air monitoring at different locations of Jaipur city on the occasion of Diwali festival. Rajasthan State Pollution Control Board.

Sagar A., Bhattacharya M. and Joon V., 2007. A comparative study of air pollution-related morbidity among exposed population of Delhi. Indian Journal of Community Medicine, 32 (4): 268-271.

Singh, D.P., Gadi, R., Mandal,T.K., Dixit, C.K., Singh,K., Saud,T., Singh,N. and Gupta,P.K., 2010. Study of temporal variation in ambient air quality during Diwali festival in India. Environmental Monitoring and Assessment, 169 : 1-13.

Suresh, S., Sehgal, M., Garg, A. and Buti, R., 2010. Is particulate matter really matters in schools ? A case study of air pollution in Delhi. Indian Journal of Environmental Protection, 30(12) : 989-998.
Thakur, B., Chakraborty, S., Debsarkar,A., Chakrabarty, S. and Srivastava, R.C., 2010. Air pollution from fireworks during festival of lights (Deepawali) in Howrah, India- a case study. Atmosfera, 23(4) : 347-365.

Toxics links, 2000.Cracking down on crackers. www.toxicslink.org.

Wang, Y., Hopke, P.K. and Rattigan, O.V., 2012. A new indicator of fireworks emissions in Rochester, New York. Environmental Monitoring and Assessment, 184 : 7293 7297.

Wang, Y., Zhuang, G., Xu, C. and An, Z., 2007. The air pollution caused by the burning of fireworks during the Lantern festival in Beijing. Atmospheric Environment, 41 : 417-431.

www.indiaenvironmentportal.org.in/, 2012. Status report of noise level/ambient air monitoring at different locations of Jaipur city on the occasion of Diwali festival. Rajasthan State Pollution Control Board.

www.toxicslink.org., 2000. Cracking down on crackers.

Zhang, M., Wang, X., Chen, J., Cheng, T., Wang, T., Yang, X., Gong, Y., Geng, F. and Chen, C., 2010. Physical characterization of aerosol particles during the Chinese New Year's firework events. Atmospheric Environment, 44 